\title{
Production and Consumption of Alcoholic Beverages with Its Consequence in India: A Short Review
}

\author{
Raghu Holalkere Sriram, Rajeshwara Achur
}

Department of Biochemistry, Kuvempu University, Shimoga, India

Email address:

hsr1983@gmail.com (R. H. Sriram)

\section{To cite this article:}

Raghu Holalkere Sriram, Rajeshwara Achur. Production and Consumption of Alcoholic Beverages with Its Consequences of in India: A Short Review. International Journal of Science and Qualitative Analysis. Vol. 4, No. 2, 2018, pp. 34-37. doi: 10.11648/j.ijsqa.20180402.11

Received: December 18, 2017; Accepted: January 16, 2018; Published: February 26, 2018

\begin{abstract}
Brewing and drinking of various liquors was developed into an art in ancient India as well as in Karnataka. Beverages are believed to contain ethanol are mentioned in ancient Indian literature dated back to Vedic period around $2000 \mathrm{~B}$. C. Ancient Indian medical texts described in details the harmful effects of excessive or indiscriminate drinking on the mind and body Ethanol or generally referred as Alcohol consumption is gradually increasing in the developing countries in the last two decades. In India, cumulative cost of alcohol consumption is more than the income due to their sale. The proportion of injuries linked to alcohol use is estimated to be $59 \%$ of all injuries in India. In 1830, Edward Dyer traveled to India and set up the India's first brewery in Kasauli. Karnataka ranks third in the country in ethanol production. India Made Foreign Liquor (IMFL), Country Liquor, Illicit liquor and Beer are the types of alcoholic beverages available in India.
\end{abstract}

Keywords: Brewing, Alcohol Consumption, India Made Foreign Liquor, Country Liquor, Illicit Liquor, Beer

\section{Introduction}

Brewing and drinking of various liquors was developed into an art in ancient India as well as in Karnataka. Beverages are believed to contain ethanol are mentioned in ancient Indian literature dated back to Vedic period around 2000 B. C [1]. Two verities of drinks are described soma and sura along with their effects and the harms that might result from excessive consumption. Several interpretations exist on the drinking habit of Kannadigas [2]. Smritis or sacred texts (like Manusmriti and Yajayavalkyasmriti) consider drinking liquor (sura) was a great sin and forbidden to certain communities (Brahmins, Jains, Veerashaivas). Karnataka is homeland of a variety of tasty and well flavored indigenous alcohols and liquors. There were mild and strong ones brewed from rice, ragi (sweet barley), palm and ichala (wild palm) and milder ones prepared from grapes, mangoes, jackfruit, coconut, and dates flavored with flower essences [3]. Alcohol was also an ingredient in many medicinal preparations in the traditional Ayurvedic medicinal system [4]. Ancient Indian medical texts described in details the harmful effects of excessive or indiscriminate drinking on the mind and body. Charaka Samhita, a 2000 year old book on medicine stats that "If a person takes it in right manner, right dose, at right time and along with wholesome food with a cheerful mind, to him wine is like ambrosia." However also states that "to a person who drinks whatever kind comes in hand to him, and whenever he gets an opportunity, this very wine acts as a poison," Despite the knowledge and availability of alcoholic beverages in India they were never a part of the normal diet in India [5]. Strict rules and guidelines governed who could drink and under what circumstances.

\section{Production and Consumption of Alcoholic Beverages in India}

In 1830, Edward Dyer traveled to India and set up the India's first brewery in Kasauli. It produced the beer brand Lion, which is still available. In 1835, the Kasauli brewery was shifted to Solan near Shimla. In 1885, it was incorporated as Dyer Breweries. By the year 1882, there were 12 breweries in India in all, including one in Rangoon [6]. In 1892, about 4,831,127 gallons of beer was produced in India. Out of this 2,748,365 gallons were purchased by commissariat and rest was left for consumption by the 
civilian population.

Currently, the country's ethanol production is likely to increase by 29 per cent to 2,170 million liters in 2012 on the back of higher sugar production India produces conventional ethanol from sugar molasses, is estimated to manufacture 26 million tones of sugar in the 2011-12 marketing year ending September, higher than the domestic demand of 22 million tones. India's ethanol production is 2,170 million liters in 2012, against 1,681 million liters last year. Domestic consumption of ethanol is 2085 million liters in 2012 compared to 1995 million liters in 2011. About 880 million liters of ethanol is likely to be used in manufacturing of portable liquor, 720 million liters for industrial use and 400 million liters for blended gasoline in 2012. Out of 330 distilleries in India, about 140 have the capacity to distill around 2 billion liters of conventional ethanol per year and could meet the demand for five per cent mandatory blending of ethanol with petrol [7]. Alcohol sales are state subjects in India and everyone looks at it as a golden goose which must be exploited to the hilt. The alcoholic beverages industry, as they say is recession-proof. With a rising and promising GDP, Rising social acceptability, conspicuous consumption and high disposable income of the globalized consumer is pushing the industry to newer heights. Also, rapid urbanization in metros and cities, is contributing further to the growth.

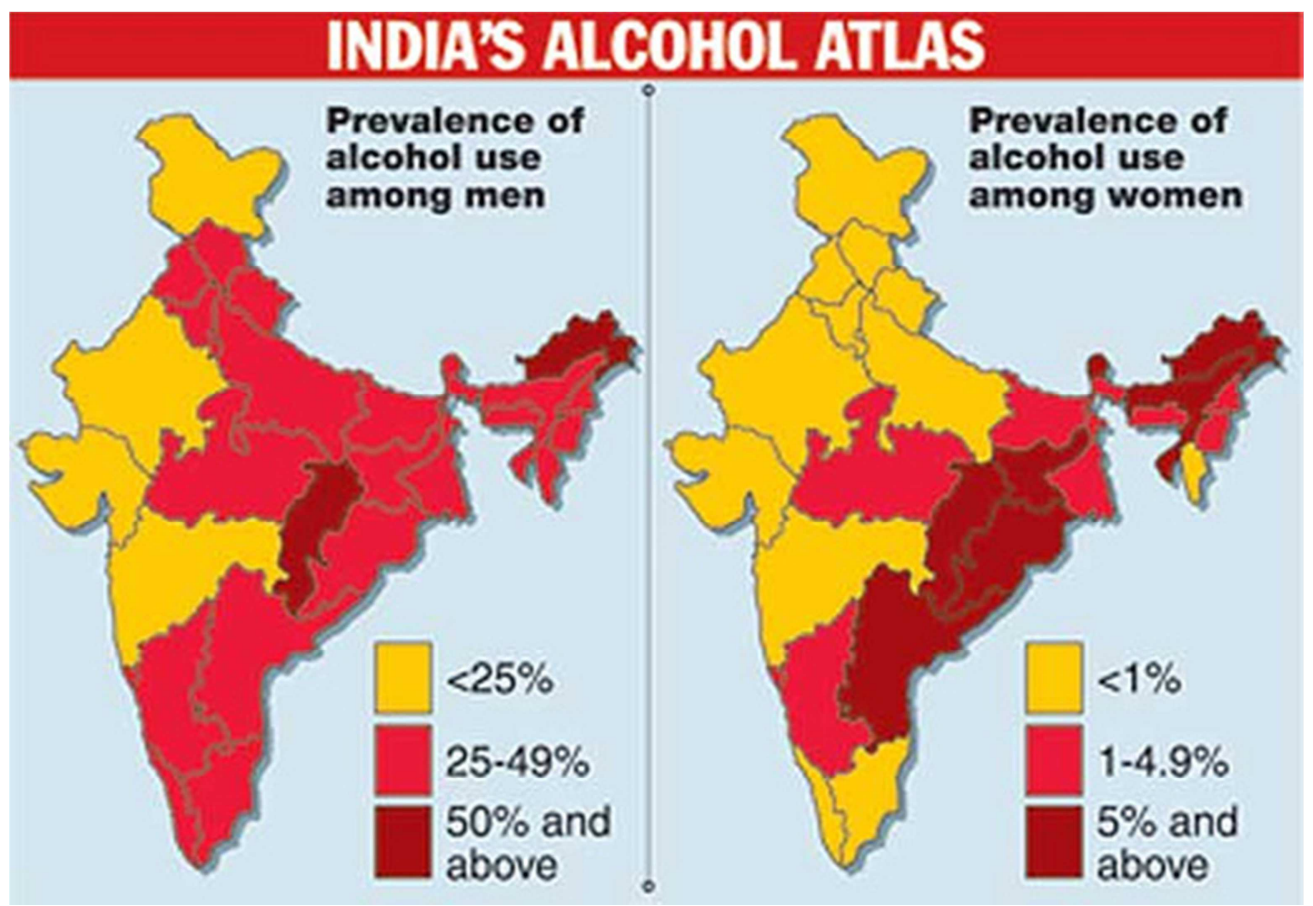

(Source: Dr. Vikram, Healthcare in India from a doctors Perspective, 2013).

Figure 1. Prevalence of alcohol use among men and women in India.

In case of Karnataka which ranks third in the country in ethanol production [8]. It has been estimated that the State ethanol production will increases from 135 million liters a year to 200 million liters a year from molasses. In Karnataka, the government is in the wholesale business, Excise revenue is currently 20 per cent of State revenue.

\section{Types of Alcoholic Beverages Available and Consumed in India}

India accounts for 22.5 percent of the total alcohol consumption. India has great variety in climate, vegetation, culture and tradition. Hence it is not surprising that hundreds of alcoholic beverages are made and consumed here. They can be grouped in to following categories.

\subsection{India Made Foreign Liquor (IMFL)}

This is created for revenue purpose, consists in western style distilled beverages such as whiskey, rum, gin, vodka and brandy. These beverages are made in India under government licenses and maximum alcohol content is $42.8 \%$. Some of these brands have all India presence. Whisky is most popular drink with hundreds of brands. India is the largest whisky market in the world. The estimated whiskey market in India in the year 2013 was about US \$10 billion or INR 541.389 billion. Dozens of rum, gin and brandy brands are available. Wines also belong to this category, but till recently the production and consumption in India was almost nonexistent.

\subsection{Country Liquor}

These distilled alcoholic beverages are made from cheap raw materials which are available locally example, sugarcane, rice or coarse grains. Country liquor is produced in licensed distilleries and sold from authorized outlets within the same district. Common varieties of Country liquor are 
arrack, desi sharab and tari (toddy). The licensing system and governmental monitoring of the production process ensures uniformity in alcohol content (around 40\%). Northern and western India are sugar producing areas where large amount of molasses is available at a very low price hence molasses is used as raw material for liquor production. In south India, coconut and other palms are used for it. Apart from this inexpensive grains are also used for the production of country liquor all over India.

\subsection{Illicit liquor}

Other than licensed distilleries a number of small production units operate illicitly. The raw materials used are similar to that of country liquor, but the alcohol concentration varies and adulteration is frequent. Most commonly the concentrations of these liquors are around $56 \%$. These are considerably less expensive than country liquor hence find a ready market among the poor. In addition to the commercial production, home production for personal consumption is also common in some parts of India. A survey of Punjab alcohol users found that $45 \%$ of them reported home liquor production for their own consumption. Home fermentation and distillations are also common in several tribal areas [9].

\subsection{Beer}

Beer is relatively recent arrival in India; however beer production and consumptions have grown rapidly. In India beer is manufactured in large licensed breweries and is available in more than 60 brands. Alcohol content varies from $5 \%$ to $9 \%$. Beer is available in bottles and cans which are recently introduced. Since the price is higher than the distilled liquor it is a drink for the middle and upper economic classes. Beer also has become the favorite beverage of urban young.

Since India's economic liberalization, the market for IMFL and imported liquors is growing fast. It is estimated that the liquor industry is expanding 30 per cent year-on-year. In 2015 , liquor consumption is pegged to touch about 20 billion litres. The total value of spirits, wine and beer consumed in India is projected to be in the neighborhood of Rs. 1.5 lakh crore in 2015.

A National Institute of Mental Health and Neurological Sciences study in Karnataka a few years ago found that for every rupee the government got off the bottle, it lost more than Rs. 2 in terms of healthcare expenses and lost productivity. The increased rate of alcohol consumption in India has adverse effects on society, economy, youth, health, safety and absenteeism. The proportion of injuries linked to alcohol use is estimated to be $59 \%$ of all injuries in India [10].

\section{Consequences of Alcohol Consumption in India}

A National Institute of Mental Health and Neurological Sciences study in Karnataka a few years ago found that for every rupee the government got off the bottle, it lost more than Rs. 2 in terms of healthcare expenses and lost productivity. The increased rate of alcohol consumption in India has adverse effects on society, economy, youth, health, safety and absenteeism. The proportion of injuries linked to alcohol use is estimated to be $59 \%$ of all injuries in India ${ }^{[10]}$.

The percapita consumption of alcohol in India is about 2 litres / adult / year (calculated from official 2003 sales and population figures). After adjusting for undocumented consumption, which accounts for $45-50 \%$ of total consumption, this is likely to be around 4 litres. The proportion of injuries 'linked' to alcohol use is estimated to be $59 \%$ of all injuries in India. Violent and deliberate injuries are significantly related to use and form the largest segment of alcohol related injuries. Out of all injuries, the one unrelated to alcohol use is $41 \%$ whereas $24 \%$ accounts for injuries due to own drinking and the remaining $35 \%$ is due to others drinking. The problem of alcoholism can be classified into following categories [10].

\subsection{Health and Safety}

It has been observed that trauma, violence, organ system damage, various cancers, unsafe sexual practices, premature death and poor nutritional status of families with heavy drinking fathers are associated with alcohol use. About 15 to $20 \%$ of traumatic brain injuries and $37 \%$ of injuries in a public hospital were due to alcohol. About $34 \%$ of those who attempted suicide were abusing alcohol.

\subsection{Work Place}

It can be noticed that, about $20 \%$ of absenteeism and $40 \%$ of accidents at work place are related to alcohol. Annual loss due to alcohol was estimated to be Rs. 70,000 to 80,000 million in India. In rural India the use of alcohol leads to loss of pay. Most workers in the rural areas are working on daily wages and inability to work due to intoxicated state leads to various other socio-economical problems.

\subsection{Family}

It has been estimated that about $85 \%$ of men who were violent towards their wives were frequent or daily users of alcohol. 3 to $45 \%$ of household expenditure is spent on alcohol. Use of alcohol increases in debtedness and reduces the ability to pay for food and education. This in turn has adverse effects on society such as lack of education, health and sanitation for childrens. It also creates a serious social problem due to inability of the family to pay for their daily expenses.

\subsection{Youth}

Young people, especially teenagers, are more sensitive to alcohol use because their body and brain are still developing. Increasingly in India, the young are being lured for alcohol use. They are impressionable, want to be seen as fun, hip, cool and 'belong' to their peer groups and friend circles. This addiction of youth towards alcohol has adverse effects on the 
growth and development of the society as well as on the economy of the country.

\subsection{Poverty by Alcohol}

Alcohol exacerbates poverty and is a hindrance to a healthy development process of a nation and society. Its economic impact is in poorest families; especially the money spent on alcohol is rather a large proportion of the family earnings. This is often under estimated. Alcohol dependence is a major health problem in India. An estimated $32-42 \%$ of adult Indian population reports high usage of alcohol in their lifetime. $5-7 \%$ is abuser of alcohol and 10-20 million persons have been estimated to be in need of treatment for alcohol dependence. The reports also indicated that there is a steady rise in per capita alcohol consumption every year [10].

\section{References}

[1] Chopra RN, Chopra IC (1965). Drug addiction with special reference to India. New Delhi: council of Scientific and Industrial Research.
[2] Dikshitar VR. (1951). Prehistoric south India. Madras: N. S. Press.

[3] Jyotsna Kamat (2013). Drinking in Ancient Karnataka. Karnataka History Academy Conference. Hampi.

[4] Prakash O. (1961). Food and drinks in ancient India. New Delhi: Munshi Ram Manohar Lal, publishers.

[5] Charak Samhita. (1949). Shree Gulabkunverda Ayurvedic Society, Jamnagar, Popular Edition, Vol. III, Chapter 24: 2203-2247.

[6] Sir William Wilson Hunter (1886). The Indian Empire: Its People, History, and Products. Asian Educational Services. p. 616. ISBN 978-81-206-1581-6.

[7] Economic times, 2012, June 27. India's 2012 Ethanol Output Likely to rise $29 \%$.

[8] The Hindu, 2012, June 6. State eyes second position in country in ethanol output.

[9] Brij Lal and Singh G, (1978). Alcohol consumption in Punjab. Indian journal of psychiatry, 20: 217.

[10] Benegal V, Velayuudham A, Jain S, (2003), Social Cost of Alcoholism: a Karnataka perspective, NIMHANS Journal, 18 (1\&2) 67. 